Tarbawy : Jurnal Pendidikan Islam

ISSN : 2407-4462 (Cetak), 2614-5812 (Elektronik)

Vol. 5, No. 2, 2018, Hal. 89 - 100

DOI: https://doi.org/10.32923/tarbawy.v5i2.836

\title{
Emosional : Tinjauan Al-Qur'an dan Relevansinya Dalam Pendidikan
}

\author{
Zulkarnain $^{1}$ \\ ${ }^{1}$ IAIN Syaikh Abdurrahman Siddik Bangka Belitung
}

\begin{tabular}{ll}
\hline \hline \multicolumn{2}{l}{ Kata Kunci: } \\
\hline
\end{tabular}

Kata Kunci :

Emosional

Al-Qur'an

Pendidikan

Keywords:

Emotional

Al-Qur'an

Education.

\section{Koresponden:}

Zulkarnain

Email: zkarnain527@gmail.com

\begin{abstract}
ABSTRAK
Emosional adalah reaksi terhadap rangsangan dari luar dan dalam diri individu. Merujuk Daniel Goleman secara emosional ke perasaan dan pikiran yang berbeda, keadaan biologis dan psikologis dan serangkaian kecenderungan untuk bertindak. Emosional berhubungan dengan perubahan fisiologis dan berbagai pemikiran. Jadi, emosi adalah salah satu aspek penting dalam kehidupan manusia, karena emosional dapat menjadi motivator perilaku dalam arti meningkatkan, tetapi juga dapat menyebabkan perilaku negatif bagi manusia. Dalam Al Qur'an, deskripsi yang cermat tentang berbagai perasaan emosional yang dirasakan oleh manusia, seperti ketakutan, kemarahan, cinta, kegembiraan, kebencian, kecemburuan, dan kesedihan diungkapkan. Al-Quran memberikan petunjuk tentang cara mengelola emosi dengan baik dan benar sehingga dapat melahirkan kecerdasan emosi. Kemudian untuk mengembangkan emosi agar memiliki dampak positif, perlu dilakukan upaya proses pembelajaran untuk berimajinasi sehingga memungkinkan mereka menyalurkan berbagai keinginan yang tidak dapat diwujudkan dalam kehidupan nyata atau menetralkan berbagai emosi negatif yang ada pada dirinya.
\end{abstract}

\begin{abstract}
Emotional is reaction to stimuli from outside and within the individual. Referring Daniel Goleman emotionally to a distinctive feeling and mind, a biological and psychological state and a series of tendencies to act. Emotional is related to physiological changes and various thoughts. So, emotional is one of the important aspects in human life, because emotional can be a behavioral motivator in the sense of improving, but can also lead to negative intentional behavior of humans. In the Qur'an, a careful description of the various emotional feelings felt by humans, such as fear, anger, love, joy, hate, jealousy, envy, and sadness is expressed. Al-Quran provides instructions on how to manage emotional well and correctly so that it can give birth to emotional intelligence. Then to develop emotions to have a positive impact, it is necessary to make the learning process efforts to fantasize so that it allows them to channel various desires that cannot be realized in real life or neutralize the various negative emotions that exist on him.
\end{abstract}

\section{Pendahuluan}

Kajian al-Qur'an tentang emosional tidak terbatas pada telaah karakter, tapi juga faktor. Faktor emosional diterangkan di dalam ayat-ayat al-Qur'an sejalan dengan kenyataan dan dinamika kehidupan manusia itu sendiri. Sementara hasil penelitian dari ayat-ayat kauniyah yang kemudian menjadi teori psikologi. Ungkapan al-Qur'an tentang emosi biasanya berupa gambaran tentang perilaku manusia dalam suatu situasi tertentu. Untuk menghadapi era globalisasi sekarang ini, manusia membutuhkan Al-Qur'an sebagai petunjuk untuk menghadapi berbagai tantangan hidup, tidak terkecuali dunia pendidikan.

Dalam ilmu jiwa, akar dari emosi merupakan ketidakpuasan terhadap sesuatu. Emosi memegang peranan penting dalam kehidupan manusia. Emosi merupakan daya terampuh yang dimiliki manusia 
sehingga dapat memberikan warna kepada kepribadian seseorang, aktivitas, penampilan bahkan kesehatan jiwanya. Emosi merupakan penyambung hidup bagi kesadaran diri dan kelangsungan diri secara mendalam, menghubungkan diri sendiri, dengan orang lain serta dengan alam dan kosmos, (Segal \& Nilandari, 2000).

Keberadaan emosi dalam diri manusia laksana pisau, dimana pada saat yang bersamaan pisau dapat membantu dan membahayakan. Semisal ketika seseorang menggunakan pisau untuk memotong sayuran, pada saat itu pula pisau dapat melukai tangan seseorang jika tidak berhati-hati dalam penggunaanya. Emosi yang dikontrol dengan baik dapat meningkatkan antusias, kepuasan, saling percaya dan komitmen yang pada gilirannya berdampak besar terhadap peningkatan kualitas kehidupan manusia,(Martin, 2003). Sebaliknya, sebagaimana yang telah manusia alami, emosi yang tidak terkontrol dengan baik sering berakibat buruk dan merugikan diri manusia itu sendiri maupun orang lain.

Memang emosional sebagai bagian penting dalam sisi kejiwaan manusia tidak akan lepas dari totalitas itu sendiri. Hampir setiap setiap tingkah laku kita punya keterkaitan tertentu dengan emosi. Menurut James, faktor yang penting dalam emosi adalah umpan balik dari perubahan badani yang terjadi sebagai respon terhadap situasi yang menakutkan dan membingungkan. Biasa orang menyadari adanya suatu yang sedang terjadi secara internal ketika mereka marah, bingung, gembira, takut, tetapi mereka tidak dapat mengamati perubahan pada tekanan darah atau aktivitas di dalam perut mereka,(Ardani, 2008) .

Secara aplikatif mengajarkan bagaimana mengendalikan emosi agar melahirkan suatu kecerdasan baru yakni kecerdasan emosional. Contohnya Nabi Muhammad saw. Mengajarkan bagaimana mengendalikan diri dari emosi marah. Salah satu faktor peredam kemarahan adalah relaksasi tubuh dan melepaskan ketegangan. Duduk dan berbaring pada saat marah dapat mengendorkan kondisi tubuh dan bisa mengurangi ketegangan yang diakibatkan oleh rasa marah, (Muhammad Utsman Najati, 2005).

Emosional berfungsi mengarahkan tingkah laku seperti halnya dorongan. Emosi takut, misalnya, akan mendorong untuk mempertahankan diri, terkadang juga mendorongnya bersikap memusuhi. Adapun emosi cinta mendorongnya untuk mendekati obyek yang dicintainya. Alqur'an sendiri menggambarkan berbagai macam-macam emosional yang dirasakan manusia. Seperti cinta, takut, marah benci, sedih, malu, iri, cemburu, dan sombong.

Tentu hal ini menjadi sangat menarik dan bermanfaat pandangan-pandangan al-Qur'an mengenai perilaku emosional dalam al-Quran dan dampak dalam dunia pendidikan. Tulisan ini diharapkan akan menyajikan perilaku emosional dalam al-Qur'an. Serta berasumsi bahwa pandangan perilaku emosional dalam al-Qur'an patut dijadikan rujukan untuk menciptakan dunia pendidikan era sekarang menjadi jati dirinya yang menjadi kunci berkepribadian yang sehat, cerdas, dan kreatif. Serta menjunjung tinggi akhlakul karimah.

\section{PEMBAHASAN}

\section{Mengenal Emosional}

Secara etimologi, emosi berasal dari akar kata bahasa latin movere yang berarti menggerakkan atau bergerak. Kemudian ditambah dengan awalan 'e' untuk memberi arti bergerak menjauh. Makna ini menyiratkan kesan bahwa kecenderungan bertindak merupakan hal mutlak dalam emosi, (Darwis, 2006). Menurut makna paling harfiah, Oxford English Dictionary, sebagaimana dikutip oleh Daniel Goleman, mendefinisikan emosi sebagai setiap kegiatan atau pergolakan pikiran, perasaan, nafsu; setiap keadaan mental yang hebat atau meluap-luap, (Goleman, 2000).

Menurut Crow \& Crow, emosi merupakan suatu keadaan yang bergejolak pada diri individu yang berfungsi sebagai inner adjustment (penyesuaian dalam diri) terhadap lingkungan untuk mencapai kesejahteraan dan keselamatan individu, (Hartati, 2004). Chaplin menjelaskan emosi bersifat lebih intens dibandingkan dengan perasaan, sehingga perubahan jasmaniah yang ditimbulkan oleh emosi lebih jelas dibandingkan perasaan. Aspek-aspek emosi mencakup perasaan subjektif, dasar fisiologis perasaan emosional, pengaruh emosi terhadap persepsi, berpikir, dan perilaku, lalu mencakup juga kelengkapan motivasional tertentu dan terakhir cara emosi ditunjukkan dalam bahasa, ekspresi wajah, dan gesture, (Syukur, 2011).

Sedangkan Silverman seorang psikolog, menyatakan bahwa emosi adalah perilaku yang terutama dipengaruhi oleh tanggapan mendalam yang terkondisikan. Menurut Hude (Darwis, 2006) bahwa emosi adalah suatu gejala psiko-fisiologis yang menimbulkan efek pada persepsi, sikap, dan tingkah laku, serta dalam bentuk ekspresi tertentu. Misalnya, emosi senang (joy) yang berkombinasi dengan penerimaan (acceptance) akan melahirkan cinta (love); emosi sedih (sadness) yang berkombinasi dengan kejutan (surprise) 
melahirkan kekecewaan mendalam (disappointment); cinta (love) berkombinasi dengan marah (anger) melahirkan kecemburuan (jealousy).

Berdasarkan pandangan beberapa ahli di atas, dapat dilihat bahwa emosi sebagai suatu keadaan efektif yang disadari di mana alaminya perasaan seperti kegembiraan, sedih, takut, benci, dan cita (dibedakan dari keadaan kognitif dan keinginan disadari) serta perasaan-perasaan yang dapat mempengaruhi perilaku, dan umumnya mengundang komponen fisiologikal dan kognitif.

Setiap perubahan yang relatif menetap dalam tingkah laku yang terjadi sebagai hasil dari latihan dan pengalaman atau perubahan kepribadian sebagai pola baru yang berupa kecakapan, sikap, kebiasaan, kepandaian. Abin Syamsudin makmun (Noer, 2015) mengatakan bahwa pembelajaran adalah suatu proses perubahan perilaku atau peribadi seseorang berdasarkan praktek atau pengalaman tertentu. Sedangkan menurut Muhibbin Syah belajar merupakan proses memperoleh pengetahuan (psikologi kognitif), (Noer, 2015).

Dalam pembelajaran yang menggunakan pendekatan emosional, perhatian akan perkembangan intelektual anak dianggap penting, hal ini sejalan dengan pandangan Semiawan bahwa "Stimulasi intelektual sangat dipengaruhi oleh keterlibatan emosional, bahkan emosi juga amat menentukan perkembangan intelektual anak secara bertahap, (Semiawan, 1997). Artinya secara timbal balik faktor kognitif juga terlibat dalam perkembangan emosional. Dengan demikian, antara IQ dengan EQ tidak dapat dipisahkan perannya satu sama lain. Keberadaan IQ sangat menunjang berfungsinya EQ, demikian pula sebaliknya, keberadaan EQ sangat menentukan fungsi IQ.

Fungsi emosi merupakan sebagai motivasi dalam bertingkah laku. Emosi juga membuat individu siap atau tidak siap untuk berinteraksi dengan lingkunannya melalui perubahan-perubahan fisiologis, (Danarjati, Murtiadi, \& Ekawati, 2014). Robert menjelaskan fungsi dalam emosi itu ada tiga diantaranya yaitu sebagai berikut:

1. Fungsinya untuk mempersiapkan seseorang yang akan berbuat sesuatu.

2. Fungsinya untuk membentuk perilaku manusia di masa depan.

3. Fungsinya untuk alat komunikasi dengan orang lain secara baik dan benar serta efektif, (Feldman, 2012).

Sehingga dalam kaitan ini peran emosi banyak terlibat aktifitas manusia. Hal ini dapat dilihat pada keadaan dalam diri kita, yang tidak disadari selalu bereaksi dalam keadaan emosi. Reaksi dalam diri ini berpengaruh pada persepsi, pembelajaran, pemikiran, dan secara umum segala apa yang kita kerjakan. Tidak seperti motivasi, emosi tidak selalu memiliki tujuan langsung, ia lebih merupakan leburan reaksi tak terorganisasi terhadap rangsangan dari luar ataupun dari dalam.

Menurut perspektif Islam, emosional identik dengan nafsu yang dianugerahkan oleh Allah SWT nafsu inilah yang akan membawanya menjadi baik atau jelek, budiman atau preman, pemurah atau pemarah, dan sebagainya. Nafsu dalam pandangan Mawardy Labay el-Sulthani yang disebutkan dalam bukunya yang berjudul Dzikir dan Do'a Menghadapi marah tersebut, nafsu terbagi dalam lima bagian yaitu:

1. Nafsu rendah yang disebut dengan nafsu hayawaniyah, yaitu nafsu yang dimiliki oleh binatang seperti keinginan untuk makan dan minum, keinginan seks, keinginan mengumpulkan harta benda, kesenangan terhadap binatang dan juga rasa takut.

2. Nafsu amarah yang artinya menarik, membawa, menghela, mendorong dan menyuruh pada kejelekan dan kejahatan saja. Nafsu amarah cenderung membawa manusia kepada perbuatanperbuatan yang negative dan berlebih-lebihan.

3. Nafsu lawwamah, yaitu nafsu yang perlu mendorong manusia untuk berbuat baik. Ini merupakan lawan dari nafsu amarah. Apa yang dikerjakan nafsu amarah terus ditentang dan dicela keras oleh nafsu lawwamah, sehingga diri akan tertegun sebentar atau berhenti sama sekali dari perbuatan yang dianjurkan amarahnya.

4. Nafsu mussawilah, yakni merupakan nafsu provokator, ahli memperkosa dan ahli memukau. Di dalam istilah perang, dia diberi julukan dengan koloni kelima, ia berkedudukan menteri kelima di kementerian peperangan dan propaganda. Karena disebut koloni kelima di pihak lawan ia perlu mendapat perhatian yang serius.

5. Nafsu mutmainnah, artinya kondisi jiwa yang seimbangatau tenang seperti permukaan danau kecil yang ditiup angin, akan jadi tenang, teduh walaupun sesekali terlihat riak kecil, nafsu mutmainnah juga berarti nafsu yang tenang dan tentram dengan berdzikir kepada Allah SWT, tunduk kepada-nya, serta jinak kala dekat dengan-nya, (Qoyyim, 2004).

Adapun pembagian emosi menurut Sigmund Freud dalam psikoanalitik dikemukakan bagianbagian kepribadian yang muncul dalam emosi itu rasa cinta, marah, terharu, heran dan lain sebagainya. 
Sedangkan Atkinson dkk (Atkinson, Atkinson, Smith, \& Bem, 1990), mengemukakan beberapa tipe emosi yang muncul dari sistem limbik antara lain:

1. Senang

Senang merupakan kebangganan dan respons cepat yang berhubungan mengurangi tensi yang menyertai daya dorongan suatu rangsangan.

2. Sedih

Sedih lawan dari senang,menjadi melempem, lemah merespons. Ini disebabkan tidak tercapai apa yang diinginkan, dan biasanya diikuti oleh suatu rasa kehilangan atau menjadi tidak terkontrol.

3. Marah

Marah merupakan kejengkalan ketika arah tujuan perbuatan dilarang atau dikecewakan, dan ini biasanya sangat rentan terhadap pengaruh komulatif (dendam).

4. Takut

Takut merupaka reaksi umum terhadap yang tidak diharapkan, tidak dikenal, dan rangsangan yang sangat kuat dalam merusak situasi biasanya.

5. Tanggapan mengejutkan

Merupakan reaksi takut yang khusus terhadap kejadian intrn yang tiba-tiba. Orang yang terkejut reaksinya bisa bermacam-macam dalam waktu bersamaan, seperti membelalakkan mata, buka mulut, pegang kepala, dan menarik leher.

6. Cinta

Cinta melibatkan peran orang lain dan biasanya akan meningkat apabila orang lain itu membalas cinta.

7. Benci

Berhubungan dengan penyerangan seseorang yang membencinya, biasanya secara aktif cenderung akan menyerang objek yang dibencinya. Situasi benci yang mencolok adalah upaya yang mencoba merusak pola kehidupan seseorang, merusak pandangan hidupnya, dan mendiskreditkan kepercayaannya. Benci diri sendiri, cemburu,dan kefanatikan dalah bentuk-bentuk lain dari marah.

8. Mood

Mood adalah kondisi emosional yang lebih lama dari pada emosi itu sendiri dan biasanya tidak terlalu intensseperti emosi.

9. Temperamen

Temperamen adalah reaksi emosional yang ajeg (persistent) yang merupakan karakteristik seseorang.

Kemudian bagaimana karakteristik emosional seseorang? Banyak pendapat para pakar tentang hal ini. Beberapa rangkuman hasil bacaan dikemukakan sebagai berikut;

1. Karakteristik emosi ditandai oleh keguncangan organisme yang disertai oleh gejala-gejala kesadaran, perilaku, dan proses fsiologis.

2. Karakteristik emosi ditandai oleh kesiapan bergerak (state of being move) yang mengandung komponen penghayatan perasaan subjektif, impuls untuk berbuat, dan kesadaran (awareness) tentang perasaan yang dihayatinya, (Semiawan, 1997)

3. Keberadaan emosi dikaitkan dengan aktivitas dalam diri, yang merefleksikan perubahan psikologikal yang akan diikuti oleh rangsangan bangkitnya emosi. Pengaruh dalam diri ini bersifat melebur (diffusive) dan merata ke seluruh tubuh.

4. Reaksi emosional cenderung lebih lama dibandingkan dengan reaksi-reaksi lainya,karena otot-otot jeroan yang halus, apabila terangsang akan lamban untuk relaksi kembali. Keajengan (persistent) semacam ini menjadikan "moods" bertahan lebih lama ketika rangsangan emosi telah hilang.

5. Reaksi emosi bersifat komulatif (commulative), yaitu reaksi tertentu pada suatu kejadian akan membawa reaksi yang sama pada saat kejadian yang lain. Cirri individu dalam berbuat dengan cara tertentu bias menyokong pengaruh komulatif ini.

Menyinggung tentang perkembangan emosi, menurut Lawrence dipengaruhi oleh dua faktor, yakni (a) keturunan (heredity), dan (b) lingkungan (environment). Ahli lain seperti Atkinson memandang bahwa perkembangan emosi meliputi:

1. Sebab perkembangan emosional karena keturuna (heredity) yang merupakan kebiasaan-kebiasaan individu yang merupakan faktor penentu sensitivitas sistem syaraf, respons dalam diri, dan pola leburan reaksi dalam diri.

2. Kematangan (maturation) juga memengaruhi perkembangan emosional, terutama sebelum respons emosional tampak kepermukaan. Organ-organ syaraf yang matang akan dapat mempersepsi 
rangsangan dengan jelas. Demikian pula proses cerebral mesti matang, sebelum emosi menjadi suatu pengalaman yang tampak.

3. Kesukacitaan (excitement), yang umumnya ada pada masa seseorang individu masih bayi mungil. Setelah umur tiga bulan perbedaan-perbedaan emosi suka cita ini mulai tampak.berawal dari masa suka cita tersebut, emosi berkembang menuju kematangan dan belajar, reaksi-reaksi tersebut makin hari makin berkembang ke arah lebih spesifik, dan beragam

4. Stimulus dari luar yang menimbulkan reaksi emosional, ketepatan dalam memberikan reaksi, dan tingkah laku seseorang, merupakan hasil belajar (learning). Ini artinya perkembangan emosional seseorang juga ditentukan oleh sebab-sebab belajar, (Uno, 2008).

\section{Emosional Tinjauan Al-Qur'an}

Kosakata yang berdenotasi emosional tidak dijumpai secara spesifik di dalam al-Qur'an, tetapi bertebaran ayat yang berbicara atau berkaitan dengan perilaku emosi yang ditampilkan manusia dalam berbagai peristiwa kehidupan, (Darwis, 2006). Ungkapan al-Qur'an tentang emosi digambarkan langsung bersama peristiwa yang terjadi. Berbagai peristiwa emosional dijelaskan di dalam al-Qur'an. Muhammad Utsman Najati mengatakan, "dalam al-Qur'an dikemukakan gambaran yang cermat tentang berbagai emosi yang dirasakan manusia, seperti takut, marah, cinta, gembira, benci, cemburu, dengki, dan sedih.

Kajian psikologi misalnya merumuskan ciri-ciri tingkah laku manusia yang membedakannya dari makhluk-makhluk lainnya dengan lima ciri: 1) Memiliki kepekaan sosial, 2) Memiliki kelangsungan, 3) Memiliki orientasi kepada tugas, 4) Mengandung nilai usaha dan perjuangan, dan 5) memiliki keunikan, (Sarwono, 1976). Pendekatan al-Qur'an yang demikian itu sangat memudahkan kita untuk melihat manusia dari berbagai dimensi, karena terkait langsung dengan realitas kehidupan sehari-hari yang tak lepas dari hubungan intrapersonal, interpersonal, dan metapersonal. Menurut al-Qur'an tingkah laku manusia memiliki karakteristik karakteristik sebagai berikut: 1) terkendali, 2) mengandung unsur tanggungjawab, 3) bersifat lahir dan batin, dan 4) berkategori tingkah laku individual dan tingkah laku kelompok, (Mubarok, 2000).

Proses kemunculan emosional melibatkan faktor psikologis maupun faktor fisiologis. Kebangkitan emosional pertama kali muncul akibat adanya stimulus atau sebuah peristiwa, yang bisa netral, positif, ataupun negatif. Stimulus tersebut kemudian ditangkap oleh reseptor, lalu melalui otak. Otak menginterpretasikan kejadian tersebut sesuai dengan kondisi pengalaman dan kebiasaan dalam mempersepsikan sebuah kejadian. Interpretasi yang dibuat kemudian memunculkan perubahan secara internal dalam tubuh. Perubahan tersebut misalnya napas tersengal, mata memerah, keluar air mata, dada menjadi sesak, perubahan raut wajah, intonasi suara, cara menatap, dan perubahan tekanan darah. Berikut ini dijelaskan perilaku emosional dasar yang diisyaratkan dalam al-Qur'an:

1. Takut

Emosi takut merupakan salah satu emosi yang sangat penting dalam kehidupan manusia, karena berperan untuk mempertahankan diri dari berbagai masalah yang dapat mengancam kehidupan itu sendiri. Emosi takut manusia dalam penuturan al-Qur'ân mempunyai cakupan yang luas. Bukan hanya gambaran ketakutan di dunia ini seperti ketakutan pada kelaparan, kehilangan jiwa dan harta, bencana alam, melainkan juga menyangkut ketakutan pada kesengsaraan hidup di akhirat.

Manfaat rasa takut tidak hanya terbatas untuk menjaga manusia dari berbagai bahaya yang mengancamnya dalam kehidupan dunianya saja. tapi di antara kemanfaatannya yang terutama sekali ialah mendorong seorang mukmin untuk memelihara dirinya dari azab Allah dalam kehidupan akhirat nanti, (M Utsman Najati, 2004). Sebab, rasa takut dari siksa Allah akan mendorong seorang mukmin untuk berusaha tidak terjatuh dalam perbuatan maksiat dan berpegang teguh dengan ketakwaan pada Allah serta disiplin dalam beribadah kepadanya dan melakukan segala sesuatu yang diridhainya.

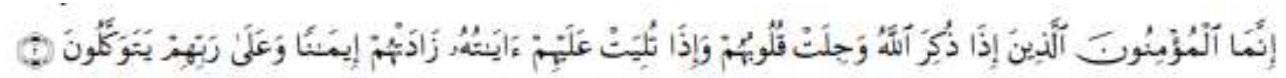

Artinya : Sesungguhnya orang-orang yang berimanialah mereka yang bila disebut nama Allah gemetarlah hati mereka, dan apabila dibacakan ayat-ayatnya bertambahlah iman mereka (karenanya), dan hanya kepada Tuhanlah mereka bertawakkal. (QS, al-Anfaal,8:2)

2. Marah

Emosi marah merupakan suatu emosi penting yang mempunyai fungsi esensial bagi kehidupan manusia,yakni membantunya dalam menjaga dirinya. Pada waktu seseorang sedang marah, 
energinya guna melakukan upaya fisik yang keras semakin meningkat. Al qur'an sendiri memberikan anjuran digunakannya kekerasan dalam menghadapi di jalan dan upaya untuk merealisasikan kekerasan dalam menghadapi orang-orang kafir yang menghalangi dalam rangka penyebaran dakwah Islam. Al Qur'an juga memberikan gambaran Nabi Musa As kepada kaumnya saat beliau mereka sedang menyembah anak sapi dari emas yang dibuat oleh Samiri.

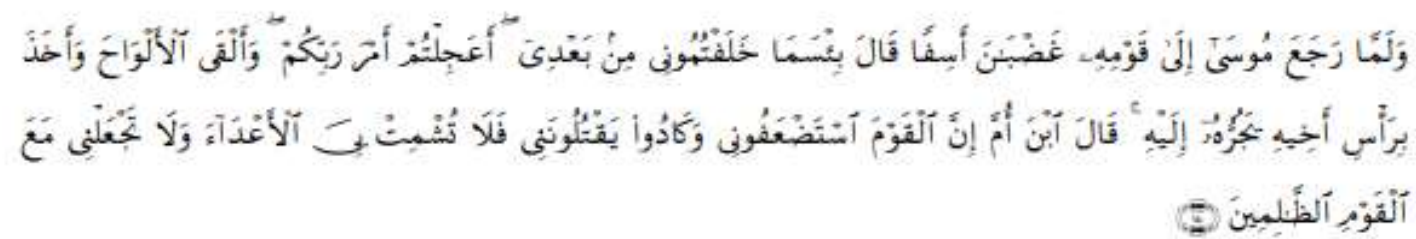

Artinya: Dan tatkala Musa telah kembali kepada kaumnya dengan marah dan sedih hati berkatalah dia: "Alangkah buruknya perbuatan yang kamu kerjakan sesudah kepergianku! Apakah kamu hendak mendahului janji Tuhanmu? dan Musapun melemparkan lauh-lauh (Taurat) itu dan memegang (rambut) kepala saudaranya (Harun) sambil menariknya ke arahnya, Harun berkata: "Hai anak ibuku, Sesungguhnya kaum ini telah menganggapku lemah dan Hampir-hampir mereka membunuhku, sebab itu janganlah kamu menjadikan musuh-musuh gembira melihatku, dan janganlah kamu masukkan aku ke dalam golongan orang-orang yang zalim". (QS. Al-A'raaf 7: 150)

Dalam al-Qur'an terdapat deskripsi tentang emosi marah dan dampaknya atas tingkah laku manusia. Ini bias didapatkan dalam uraian tentang kemarahan Nabi Musa AS ketika ia kembali pada kaumnya dan didapatkannya mereka menyembah anak sapi dari emas dibuat oleh sami. Maka Nabi Musa pertama-tama dia lampiaskan amarahnya kepada saudaranya Yaitu Harun, dan memegang kepalanya dengan rasa penuh kemarahan.

3. Cinta

Cinta memainkan peranan yang penting dalam kehidupan manusia, sebab ia merupakan landasan kehidupan perkawinan, pembentukkan keluarga, dan pemeliharaan anak. Dalam tataran agama, cinta adalah pengikat antara manusia dengan tuhannya, dan berpegang teguh pada syariatnya. Cinta juga merupakan kontak batin yang menghubungkan kaum muslim dengan rasulnya, yang membuat mereka berpegang teguh pada sunnahnya, mengikuti anjuranya, dan menjadikannya sebagai suriteladan sepanjang masa, (Ardani, 2008).

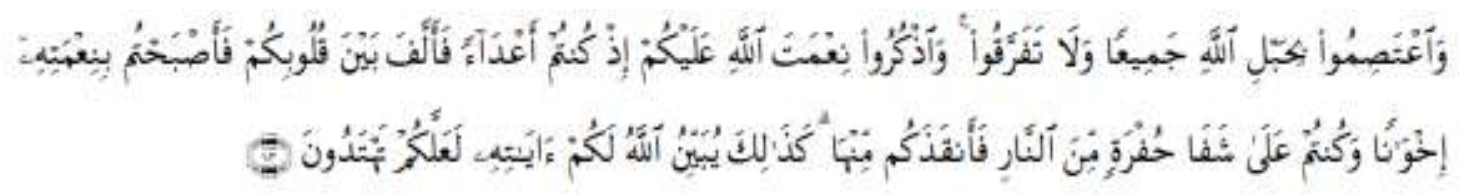

Artinya : Dan berpeganglah kamu semuanya kepada tali (agama) Allah, dan janganlah kamu bercerai berai, dan ingatlah akan nikmat Allah kepadamu ketika kamu dahulu (masa Jahiliyah) bermusuhmusuhan, Maka Allah mempersatukan hatimu, lalu menjadilah kamu karena nikmat Allah, orangorang yang bersaudara; dan kamu telah berada di tepi jurang neraka, lalu Allah menyelamatkan kamu dari padanya. Demikianlah Allah menerangkan ayat-ayat-Nya kepadamu, agar kamu mendapat petunjuk. (QS. Ali Imran, 3: 103).

4. Gembira

Gembira adalah ekspresi dari kalangan, yaitu perasaan terbebas dari ketegangan. Biasanya kegembiraan itu disebabkan oleh hal-hal yang bersifat tiba-tiba (surprise) dan kegembiraan biasanya bersifat sosial, yaitu melibatkan orang-orang lain di sekitar orang yang gembira tersebut, (Shaleh, 2008). 


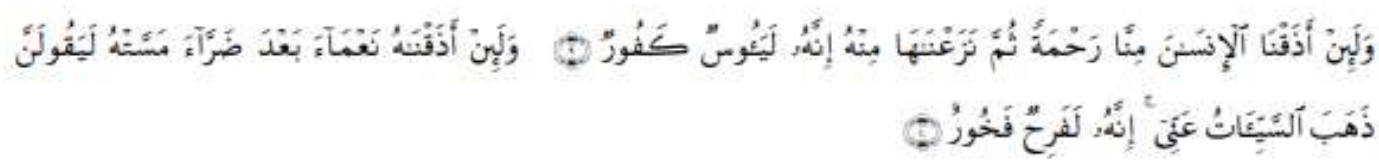

Artinya : Dan jika Kami rasakan kepada manusia suatu rahmat (nikmat) dari Kami, kemudian rahmat itu Kami cabut daripadanya, pastilah Dia menjadi putus asa lagi tidak berterima kasih. dan jika Kami rasakan kepadanya kebahagiaan sesudah bencana yang menimpanya, niscaya Dia akan berkata: "Telah hilang bencana-bencana itu daripadaku"; Sesungguhnya Dia sangat gembira lagi bangga. ( QS. Huud 11: 9-10)

5. Benci

Emosi benci merupakan kebalikan dari emosi cinta yaitu ungkapan dan rasa ketidaksenanagan, penolakan atau rasa Muak, dan berupaya menjauhi perkara-perkara yang menimbulakan rasa benci. Rasa beci dapat disebabkan oleh beberapa hal, yaitu:a) Perbedaan pendapat, b) Rasa cemburu terhadap kemenangan orang lain, c) Perbuatan yang melecehkan, d) Gaya bicara yang tinggi, e) Sikap angkuh, dan f) Gaya pakaian yang sensasional, (Muhammad Utsman Najati, 2005).

Mengisyaratkan emosi benci yang sering terjadi sebagaimana tergambar dalam al-Qur'an, umumnya mengarahkan kepada kebencian terhadap kebenaran yang datang dari Allah Swt berupa wahyu itu sendiri. Tema-tema kebencian dalam al-Qur'an terhitung sangat sedikit dibandingkan tema-tema antonimnya, semisal kesenangan.

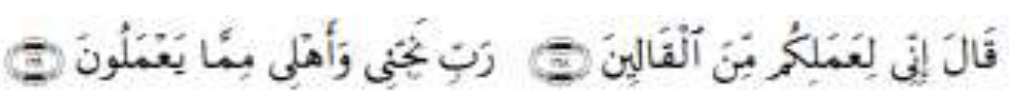

Artinya : Luth berkata: "Sesungguhnya aku sangat benci kepada perbuatanmu". (Luth berdoa): "Ya Tuhanku selamatkanlah aku beserta keluargaku dari (akibat) perbuatan yang mereka kerjakan". (QS. Asy Syu'araa' 26: 168-169)

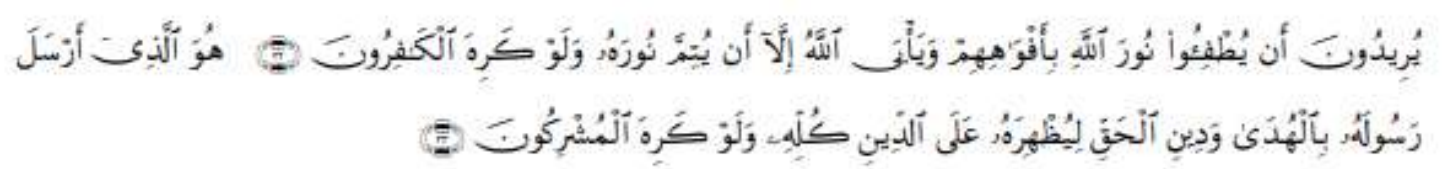

Artinya: Mereka berkehendak memadamkan cahaya (agama) Allah dengan mulut (ucapan- ucapan) mereka, dan Allah tidak menghendaki selain menyempurnakan cahayaNya, walaupun orang-orang yang kafir tidak menyukai. Dialah yang telah mengutus RasulNya (dengan membawa) petunjuk (AlQuran) dan agama yang benar untuk dimenangkanNya atas segala agama, walaupun orang-orang musyrikin tidak menyukai. (QS. At-Taubah 9:32-33)

6. Cemburu

Cemburu adalah bentuk khusus dari kekhawatiran yang didasari oleh kurang adanya keyakinan terhadap diri sendiri dan ketakutan akan kehilangan kasih saying dari seseorang. Seseorang yang mempunyai rasa cemburu selalu mempunyai sikap benci terhadap saingannya, (Shaleh, 2008) . Rasa cemburu di kalangan sesama saudara ini pun diungkapan oleh al-Qur'an dalam kisah Nabi Yusuf As dikisahkan bahwa saudara-saudara yusuf merasa cemburu kepadanya dan adiknya, karena Nabi Ya'qub As lebih cinta kepadanya dan adiknya dari pada kepada mereka:

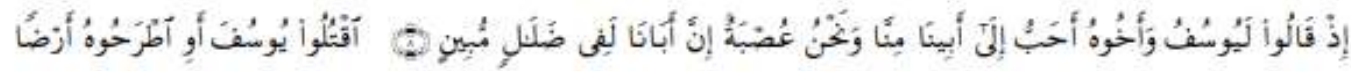

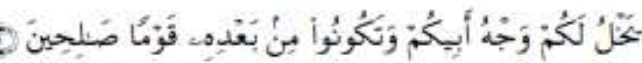

Artinya : (yaitu) ketika mereka berkata: "Sesungguhnya Yusuf dan saudara kandungnya (Bunyamin) lebih dicintai oleh ayah kita dari pada kita sendiri, Padahal kita (ini) adalah satu golongan (yang kuat). Sesungguhnya ayah kita adalah dalam kekeliruan yang nyata. bunuhlah Yusuf atau buanglah Dia 
kesuatu daerah (yang tak dikenal) supaya perhatian ayahmu tertumpah kepadamu saja, dan sesudah itu hendaklah kamu menjadi orang-orang yang baik. (QS. Yusuf, 12: 8-9)

7. Dengki

Dengki merupakan emosi yang dirasakan seseorang bila melihat orang lain memiliki sesuatu yang ia harapkan menjadi milikinya, bukan menjadi milik orang lain, (Muhammad Utsman Najati, 2005). Kedengkian yang demikian ini diungkapakan dalam al-Qur'an dalam kisah tentang Karun. Dituturkan bahwa karun keluar kepada kaumnya dengan penuh kemegahan. Ini membuat kaumnya merasa dengki kepadanya, mereka menginginkan hendaknya mereka bisa mempunyai harta dan emas seperti yang dimiliki Karun:

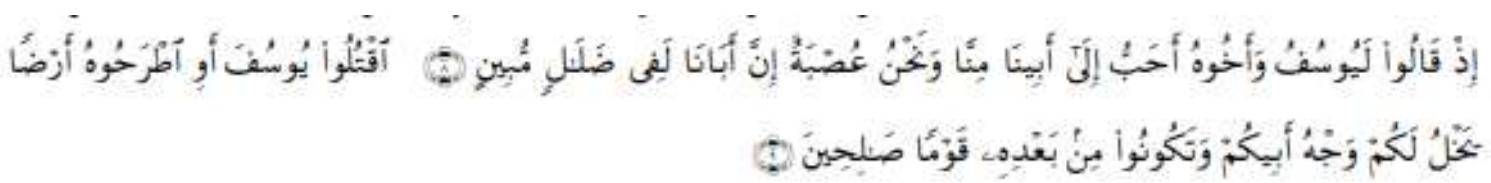

Artinya : Maka keluarlah Karun kepada kaumnya dalam kemegahannya. berkatalah orang-orang yang menghendaki kehidupan dunia: "Moga-moga kiranya kita mempunyai seperti apa yang telah diberikan kepada Karun; Sesungguhnya ia benar-benar mempunyai keberuntungan yang besar". (QS. Al-Qashash, 28: 79).

Kemudian selanjutnya dalam al-Qur'an diungkap pula kedengkian-kedengkian orang-orang Yahudi dan musyrik terhadap anugrah kenabian yang dikaruniakan kepada Nabi Muhammad Saw, dan kedengkian mereka pada karunia keimanan dan petunjuk yang diberikan-nya kepada orangorang mukmin.

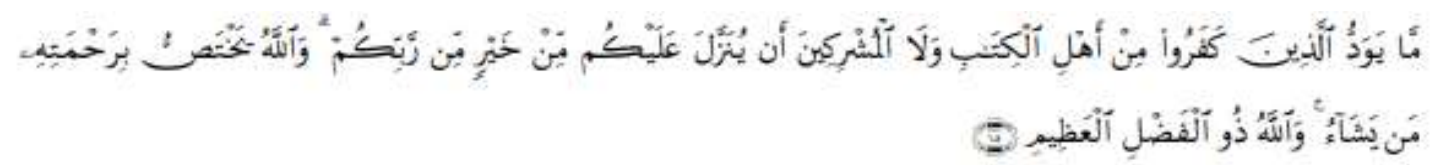

Artinya : Orang-orang kafir dari ahli kitab dan orang-orang musyrik tiada menginginkan diturunkannya sesuatu kebaikan kepadamu dari Tuhanmu. dan Allah menentukan siapa yang dikehendaki-Nya (untuk diberi) rahmat-Nya (kenabian); dan Allah mempunyai karunia yang besar. (QS. AlBaqarah, 2:105)

8. Sedih

Sedih merupakan lawan dari emosi gembira. Rasa sedih ini bisa terjadi apabila seseorang kehilangan orang lain yang akrab dengannya, atau sesuatu yang tinggi nilainya, atau apabila ia tertimpa suatu malapetaka, ataupun gagal dalam merealisasikan suatu urusan yang sangat penting, (Muhammad Utsman Najati, 2005). Dalam al-Qur'an mengisyaratkan kesedihan seorang ibu kepada anaknya Nabi Musa As, saat Nabi Musa As jauh dari ibunya, yang menaruhnya di dalam peti dan menghanyutkan kesungai.

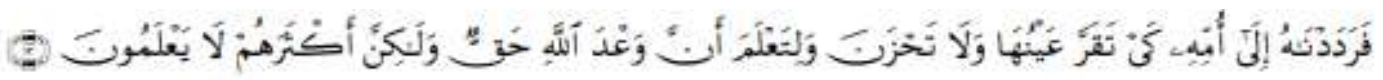

Artinya : Maka Kami kembalikan Musa kepada ibunya, supaya senang hatinya dan tidak berduka cita dan supaya ia mengetahui bahwa janji Allah itu adalah benar, tetapi kebanyakan manusia tidak mengetahuinya. (QS. Al-Qashash, 28: 13) 
Al-Qur'an juga menggambarkan kesedihan yang dialaminya Nabi Ya'qub As kehilangan putera kesayangannya, nabi Yusuf As:

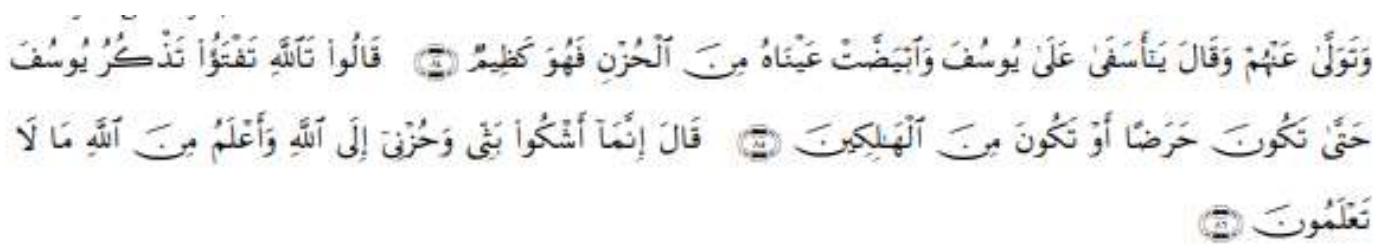

Artinya: Dan Ya'qub berpaling dari mereka (anak-anaknya) seraya berkata: "Aduhai duka citaku terhadap Yusuf", dan kedua matanya menjadi putih karena Kesedihan dan Dia adalah seorang yang menahan amarahnya (terhadap anak-anaknya). Mereka berkata: "Demi Allah, Senantiasa kamu mengingati Yusuf, sehingga kamu mengidapkan penyakit yang berat atau Termasuk orang-orang yang binasa". Ya'qub menjawab: "Sesungguhnya hanyalah kepada Allah aku mengadukan kesusahan dan kesedihanku, dan aku mengetahui dari Allah apa yang kamu tiada mengetahuinya. "( QS. Yusuf, 12: 84-86).

\section{Relevansi Emosional dalam Pendidikan}

Al-Quran memberikan petunjuk bagaimana mengelola emosi secara baik dan benar sehingga dapat melahirkan kecerdasan emosional memecah masalah menjadi persoalan yang sering bersifat ferenial dalam sejarah kehidupan manusia. Para ahli psikologi menyebutkan bahwa IQ hanya mempunyai peran sekitar $20 \%$ dalam menentukan keberhasilan hidup, sedangkan $80 \%$ sisianya ditentukan oleh faktor-faktor lain. Diantarnya yang terpenting adalah kecerdasan emosional. Dalam kehidupan banyak sekali masalahmasalah yang tidak dapat dipecah semata dengan menggunakan kemampuan intelektual seseorang. Kematangan emosi ternyata sangat menentukan keberhasilannya, dampaknya sangat besar dalam mencapai keberhasilan hidup, (Mustaqim \& Ismail, 2001).

Menurut Meier (Khodijah, 2006) emosional berpengaruh besar pada kualitas dan kuantitas belajar. Emosional yang positif dapat mempercepat proses belajar dan mencapai hasil belajar yang lebih baik, sebaliknya emosional yang negatif dapat memperlambat belajar atau bahkan menghentikannya sama sekali. Oleh karena itu, pembelajaran yang berhasil haruslah dimulai dengan menciptakan emosi positif pada diri pembelajar. Untuk menciptakan emosional positif pada diri siswa dapat dilakukan dengan berbagai cara, diantaranya adalah dengan menciptakan lingkungan belajar yang menyenangkan dan dengan penciptaan kegembiraan belajar.

Mendidik dan mengajar anak-anak agar tidak menyimpang dari fitrahnya. Dalam Al-Quran dan Hadist disebutkan bahwa manusia sejak lahir membawa fitrahnya yakni beragama islam, Seperti dalam firman Allah dalam Al-Quran surat Ar-Rum ayat, 30: 30

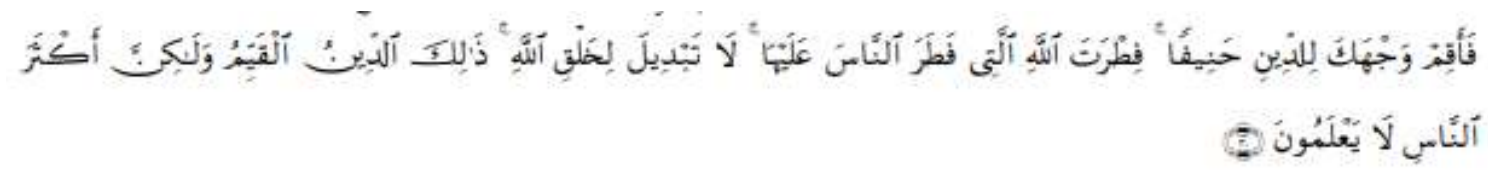

Artinya : Maka hadapkanlah wajahmu dengan Lurus kepada agama Allah; (tetaplah atas) fitrah Allah yang telah menciptakan manusia menurut fitrah itu. tidak ada peubahan pada fitrah Allah. (Itulah) agama yang lurus; tetapi kebanyakan manusia tidak mengetahui

Rasulullah bersabda :"Setiap anak yang dilahirkan itu telah membawa fitah beragama( perasaan percaya kepada Allah_, maka kedua orangtuanyalah yang menjadikan ia beragama yahudi, nasrani dan majusi" (HR Al-Baihaqi)

Kemudian tujuan ini bisa dijabarkan lagi menjadi beberapa tujuan yang lebih khusus lagi, yaitu : a) Menanamkan rasa keagamaan pada anak, b) Memperkenalkan ajaran agama IslamMelatih untuk 
menjalankan ajaran Islam, c) Membiasakan berakhlak mulia, d) Mengajarkan dan mengamalkan AlQuran, dan e) Berbakti kepada kedua orangtua, (Amin \& Zirzis, 2009).

Menurut Joyce \& Shower (Joyce \& Shower, 2000), beberapa model belajar yang dapat digunakan untuk mengembangkan aspek emosional anak dalam pembelajaran, antara lain:

1. Model Personal

Model ini memfokuskan pada diri anak sebagai bagian sentral dalam keseluruhan proses dengan tujuan: a) mengenali dan mengembangkan emosi melalui perbaikan konsep diri, b) melatih anak untuk bertanggung jawab terhadap proses pendidikan yang dijalankan dengan menciptakan tujuan belajar yang berasal dari kebutuhan dan aspirasi anak, dan c) mengembangkan cara berpikir kualitatif, seperti kreativitas dan ekspresi diri. Model tersebut dilakukan dengan cara memberikan kebebasan pada anak untuk mengekspresikan emosi dan perasaan tanpa adanya kritikan dan memberikan kesempatan pada anak untuk membuat perencanaan serta menentukan keputusan sendiri dalam mencapai tujuan belajar.

2. Model Simulasi

Model ini didasarkan pada prinsip cybernetics, yaitu menganalogikan manusia dengan mesin. Maksudnya melalui prinsip tersebut, anak diibaratkan sebagai sebuah mesin yang dapat mengatur umpan balik terhadap dirinya sendiri. Model ini memungkinkan anak untuk mengalami secara langsung situasi belajar, sehingga anak dapat merasakan dan selanjutnya memperbaiki perilaku yang masih belum tepat.

3. Model Bermain Peran

Dalam pelaksanaannya model ini membuka peluang bagi anak untuk berperan dalam berbagai karakteristik kepribadian sehingga memungkinkan adanya eksplorasi perasaan dan ekspresi emosi serta memberikan pengalaman baru terhadap sikap, persepsi maupun nilai-nilai. Selain itu melalui bermain peran yang berbeda-beda, anak dapat melatih keterampilan untuk memecahkan masalah dari berbagai sudut pandang.

Meier juga mengungkapkan kegembiraan belajar seringkali merupakan penentu utama kualitas dan kuantitas belajar yang dapat terjadi. Kegembiraan bukan berarti menciptakan suasana kelas yang ribut dan penuh hura-hura. Akan tetapi kegembiraan berarti bangkitnya pemahaman dan nilai yang membahagiakan pada diri pembelajar,(Khodijah, 2006). antara lain

Upaya pendidik Untuk Meningkatkan Perkembangan Emosional Anak Dalam Proses Pembelajaran

1. Acknowledgement Time. Guru dapat mengatur waktu di sela-sela pembelajaran untuk membimbing anak-anak mengekspresikan perasaannya dan melibatkan tentang cara-cara mengatasi perasaan tersebut. Guru mendorong anak untuk mengekspresikan perhatian atau penghargaan kepada orang lain yang bersikap baik kepada mereka.

2. Feeling Time. Tujuannya adalah membiarkan anak-anak untuk mengemukakan tentang penyebab dari emosi yang dirasakan, apa yang mereka lakukan dengan emosi tersebut, bagaimana mereka berpikir untuk membuat emosi itu berkurang, apa yang dipikirkan mereka tentang cara anak lain dalam menghadapi emosi tersebut.

3. Affection Activities. Dalam proses pembelajaran, guru dapat membuat beberapa kegiatan dimana anak dapat menunjukkan afeksinya kepada anak lain. Tujuannya ialah mengajarkan anak-anak mengenai bagaimana menjalin pertemanan dan mengekspresikan emosinya secara tepat.

4. Emotional Management Techniques. Tujuan dari cara ini adalah agar anak dapat mengatur diri dan kemampuannya apabila mengekpresikan emosi negatif di luar kendali dirinya.

5. Social Problem Solving Approach. Tujuan strategi ini adalah menolong anak untuk menyelesaikan permasalahan dalam hubungan interpersonalnya, dengan melibatkan sifat empati, cara berkomunikasi yang baik, negosiasi, kompromi. Langkah yang dapat digunakan adalah bermain peran dengan membiarkan anak-anak dalam memecahkan masalahnya sendiri, (Ashiabi, 2000).

Karena itu, pembelajaran yang berhasil harus dimulai dengan menciptakan emosi positif pada diri pembelajar jika siswa mengalami emosi positif, mereka dapat menggunakan tugas-tugas belajar yang baik. Kemudian untuk mengembangkan emosional agar berdampak positif, maka perlu dilakukan upaya proses belajar yang salah satunya dengan menggunakan metode atau kegiatan bermain. Dengan bermain, anak dapat berfantasi sehingga memungkinkannya untuk menyalurkan berbagai keinginan-keinginannya yang 
tidak dapat direalisasikan dalam kehidupan nyata ataupun menetralisir berbagai emosi negatif yang ada pada dirinya seperti rasa takut, marah dan cemas.

\section{Kesimpulan}

Melalui pendekatan tinjauan al-Qur'an yang demikian itu sangat memudahkan kita untuk melihat gambaran tingkah laku manusia dari berbagai dimensi, karena ungkapan al-Qur'an tentang emosional digambarkan langsung bersama peristiwa yang terjadi. dengan realitas kehidupan sehari-hari yang tak lepas dari hubungan intrapersonal, interpersonal, dan metapersonal. Seperti, emosional takut, emosional marah, emosional cinta, emosional gembira, emosional benci, emosional cemburu, emosional dengki, emosional sedih.

Berdasarkan tafsiran psikologi modern jelas tidak lebih berbeda sudut pandangan tentang emosional bahwa perilaku yang terutama dipengaruhi oleh tanggapan mendalam yang terkondisikan suatu gejala psiko-fisiologis yang menimbulkan efek pada persepsi, sikap, dan tingkah laku, serta dalam bentuk ekspresi tertentu. Sehingga keadaan efektif yang disadari di mana alaminya perasaan seperti kegembiraan, sedih, takut, benci, dan cita (dibedakan dari keadaan kognitif dan keinginan disadari) serta perasaanperasaan yang dapat mempengaruhi perilaku, dan umumnya mengundang komponen fisiologikal dan kognitif.

Dalam pembelajaran yang menggunakan pendekatan emosional, perhatian akan perkembangan intelektual anak dianggap penting, hal ini "Stimulasi intelektual sangat dipengaruhi oleh keterlibatan emosional, bahkan emosi juga amat menentukan perkembangan intelektual anak secara bertahap. Artinya secara timbal balik faktor kognitif juga terlibat dalam perkembangan emosional. Dengan demikian, antara IQ dengan EQ tidak dapat dipisahkan perannya satu sama lain. Keberadaan IQ sangat menunjang berfungsinya EQ, demikian pula sebaliknya, keberadaan EQ sangat menentukan fungsi IQ.

Dampak emosional dalam pembelajaran sangat besar pengaruhnya baik pada kualitas maupun kuantitas belajar pada anak. Dalam dunia pendidikan, antara keluarga, sekolah, dan masyarakat harus berdampak dalam hal memupuk emosional positif anak. Sehingga tidak menetralisir berbagai emosi-emosi negatif yang ada pada dirinya seperti rasa takut, marah dan cemas. pembelajaran yang berhasil haruslah dimulai dengan menciptakan emosi positif pada diri pembelajar. Emosional positif bisa menciptakan suasana lingkungan belajar yang menyenangkan atau kegembiraan belajar.

\section{Referensi}

Amin, S. M., \& Zirzis, A. (2009). Ilmu dakwah. Amzah.

Ardani, T. A. (2008). Psikiatri Islam. UIN-Malang Press.

Ashiabi, G. S. (2000). To Improve Developing Aspect of Emotion of The Children. Department of Child And Family Studies, University of Tennesse, Knoxville. Early Childhood Education Journal, 28(2).

Atkinson, R. L., Atkinson, R. C., Smith, E. E., \& Bem, D. J. (1990). Introduction to psychology. Harcourt Brace Jovanovich.

Danarjati, D. P., Murtiadi, A., \& Ekawati, A. R. (2014). Psikologi Pendidikan. Yogyakarta: Graha Ilmu.

Darwis, M. (2006). Emosi Penjelajahan Religio-Psikologis Tentang Emosi Manusia didalam Al Qur'an. Jakarta: PT: Gelora Aksara Pratama.

Feldman, R. S. (2012). Pengantar psikologi. Jakarta: Salemba Humanika.

Goleman, D. (2000). Kecerdasan emosional. Gramedia Pustaka Utama.

Hartati, N. (2004). dkk, Islam dan Psikologi, Jakarta: PT. Raja Grafindo Persada.

Joyce, B. W., \& Shower, B. (2000). Models of Teaching Fourth Edition Massa Chusettes. Allyn and Bacon Publising Company.

Khodijah, N. (2006). Psikologi Belajar. Palembang.: IAIN Raden Fatah Press Tersedia Dari Http://www. 
Andradogi. Com (Diakses Tanggal 2 Mei 2011).

Martin, A. D. (2003). Emotional quality management: Refleksi, revisi dan revitalisasi hidup melalui kekuatan emosi. Penerbit Arga.

Mubarok, A. (2000). Jiwa dalam al-Qur'an. Jakarta: Paramadina.

Mustaqim, H., \& Ismail, S. M. (2001). Psikologi pendidikan. Fakultas Tarbiyah Iain.

Najati, M. U. (2004). Al-Qur'an dan Ilmu Jiwa, penerjemah: Ahmad Rofi'Utsmani. Bandung: Pustaka.

Najati, M. U. (2005). Psikologi Nabi: Membangun Pesona Diri dengan Ajaran-ajaran Nabi SAW. Bandung: Pustaka Hidayah.

Noer, R. (2015). Psikologi Pendidikan. Yogyakarta: Kalimedia.

Qoyyim, I. (2004). Tazkiyatun Nafs. Solo: Pustaka Arafah.

Sarwono, S. W. (1976). Pengantar umum psikologi. Bulan Bintang.

Segal, J., \& Nilandari, A. (2000). Melejitkan kepekaan emosional: Cara baru praktis untuk mendayagunakan potensi insting dan kekuatan emosi anda. Penerbit Kaifa.

Semiawan, C. (1997). Perspektif pendidikan anak berbakat. Penerbit PT Grasindo.

Shaleh, A. R. (2008). Psikologi: Suatu Pengantar dalam Perspektif Islam. Prenada Media.

Syukur, A. (2011). Beragam cara terapi gangguan emosi sehari-hari. Yogyakarta: Diva Perss.

Uno, H. B. (2008). Orientasi Baru dalam Psikologi Pembelajaran, cet. Ke-2, Jakarta: PT Bumi Aksara. 